\title{
PEMANFAATAN APLIKASI DISCORD SEBAGAI MEDIA PEMBELAJARAN ONLINE
}

\author{
Jagad Aditya Dewantara ${ }^{1}$ Efriani $^{*}$, Afandi ${ }^{3}$ \\ ${ }^{1}$ Program Studi Pendidikan Kewarganegaraan, Universitas Tajungpura, Indonesia \\ ${ }^{2}$ Program Studi Antropologi, Universitas Tajungpura, Indonesia \\ 3Program Studi Pendidikan Biologi, Universitas Tajungpura, Indonesia \\ Jl. Prof. Hadari Nawawi, Pontianak \\ *Corresponding Author: efriani@fisip.untan.ac.id
}

\begin{abstract}
ABSTRAK
Masalah yang umum dirasakan pendidik era modern ini adalah sulitnya menemukan metode yang tepat dan praktis dalam memanfaatkan tehnologi dalam pembelajaran kelas. Artikel ini bertujuan menyajikan satu metode pembelajaran daring dengan menggunakan aplikasi discord. Metode yang digunakan dalam penelitian ini adalah kualitatif deskriftif, dengan analisis data menggunakan observasi, dan dokumentasi lapang. Penelitian lapang yang telah dilaksanakan pada dua kelas yang berbeda yaitu kelas kedokteran umum dan Pendidikan kewarganegaraan Universitas Tanjungpura telah menunjukan hasil dan data secara deskriptif kualitatif. penelitian ini membuktikan bahwa discord dapat dijadikan media dan sarana pembelajaran berbasis online. Hasil penelitan lapang ini dapat dibuktikan dengan melihat kondisi pembelajaran pada saat menggunakan aplikasi discord yang mampu menciptakan iklim debat sosial antara dua kelas berbeda yang interaktif, menyenangkan dan santai. Implikasi dari penelitian ini mempunyai manfaat praktis yang juga dirasakan pendidik dan mahasiswa dalam sharing keilmuan, sehingga discord dapat menjadi sebuah solusi praktis dan alternatif dalam kuliah online.
\end{abstract}

Kata Kunci: Discord, E-Learning, Smartphone, Media Pembelajaran

\begin{abstract}
A common problem felt by educators of this modern era is the difficulty of finding appropriate and practical methods in utilizing technology in classroom learning. This article aims to present an online learning method using the discord application. The method used in this research is descriptive qualitative, with data analysis using observation, and field documentation. Field research that has been carried out in two different classes, namely general medicine class and Citizenship Education at Tanjungpura University, has shown descriptive qualitative results and data. This research proves that discord application can be used as a media and onlinebased learning tool. The results of this field research can be proven by looking at the learning conditions when using the discord application which is able to create a climate of social debate between two different classes that is interactive, fun and relaxed. The implications of this research have practical benefits that are also felt by educators and students in sharing knowledge, so discord can be a practical and alternative solution in online lectures.
\end{abstract}

Keywords: Discord, E-Learning, Smartphone, Learning Media

JTIP@Attribution-ShareAlike 4.0 International License

\section{PENDAHULUAN}

Era digital di abad 21 telah merubah pardigma baru dalam pembelajaran di kelas bagi para pendidik. Namun, tantangan terbesar di era ini adalah peningkatan sistem pendidikan yang ada di Indonesia dalam mengadopsi dan mengimplementasikan revolusi industri (Industri 4.0) di dalam pembelajaran kelas. Hal ini, menyebabkan semua institusi Pendidikan di Indonesia harus menyelaraskan paham digital untuk dapat beradaptasi dalam menyelaraskan pola pekerjaan yang terus berkembang [1].
Salah satu kunci Pendidikan Tinggi dapat beradaptasi dengan perkembangan zaman di era digital ini adalah menerapkan proses pembelajaran blended learning yang mengkombinasikan pembelajaran online dengan pembelajaran tradisional (tatap muka) [2]. Oleh karena itu, pentingnya blended learning digunakan sebagai suatu pendekatan dalam pembelajaran yang menggabungkan antara tatap muka dan online adalah untuk saling melengkapi kekurangan satu sama lain dari kedua proses pembelajaran tersebut [3]. 
Salah satu media dan sarana yang sering digunakan pendidik dalam kuliah online antara lain google classroom, dan LMS Moodle yang biasa dipakai untuk komunikasi dalam kuliah berbasis blended learning [5]. Namun jarang seorang pengajar mengunakan dan memanfaatkan aplikasi android untuk melaksanakan pembelajaran dalam perkuliahan, salah satu aplikasi android yang digunakan adalah aplikasi Discord. Discord adalah sebuah aplikasi yang sering digunakan dan dimanfaatkan oleh para Gamers untuk berkomunikasi [6]. Kelebihan dari aplikasi Discord, pengguna dapat berkomunikasi seperti telepon dengan kualitas suara yang jernih, bahkan bisa membuat server sendiri untuk dalam menjalin komunikasi. Penggunaan discord juga dapat memfasilitasi para penggunanya untuk membuat channel sendiri sehingga bisa membuat sebuah komunikasi grup dalam lingkup yang tidak terbatas. Dalam hal ini discord juga dapat menilai pengetahuan peserta didik, memberikan umpan balik, bahkan dapat menjalin sebuah kolaborasi dan komunikasi antar seluruh peserta didik dan pengajar tanpa melalui tatap muka. Selanjutnya, bahwa penggunaan e-learning dapat menjadi alat bantu yang sangat berguna dalam mengimplementasikan pedagogi atau interaksi belajar-mengajar online [7].

Pembelajaran menggunakan discord dalam pembelajaran blended learning dapat menjadi alternatif selain menggunakan Google classroom atau LSM Moodle. Namun aplikasi Discord juga dapat diimplementasikan dan dikombinasikan secara terpisah dengan pembelajaran e-learning lainya. Oleh karena itu, tujuan dari penelitian ini adalah untuk mendeskripsikan pemanfataan aplikasi android dalam pembelajaran online di era digital sebagai media pembelajaran yakni aplikasi Discord.

\section{METODE}

Penelitian ini menggunakan metode pendekatan kualitatif deskriptif yang data diperoleh dari hasil observasi pada saat melakukan perkuliahan [8] yang menggunakan discord. Penelitian kualitatif diambil dengan tujuan dapat lebih mendalam saat mengamati mahasiswa yang sedang melakukan pembelajaran discord. Penulis juga menjelaskan bagaimana cara kerja discord untuk dipakai di dalam perkuliahan online tanpa tatap muka. Peneliti juga mengambil kerangka paradigma dalam penelitian yang dapat menjelaskan cara pandang peneliti terhadap fakta di lapangan dan perlakuan peneliti terhadap penggunakan discord, dalam hal ini peneliti juga sebagai partisipan dan pelaku di lapangan [9]. Secara umum, paradigma penelitian dapat diklasifikasikan menjadi 2 kelompok yang berbeda yaitu penelitian dalam bentuk kuantitatif dan penelitian kualitatif natural setting [10]. Selanjutnya, dalam pengambilan data observasi melibatkan 2 kelas yang berbeda yaitu kelas Pendidikan Pancasila dan kewarganegaraan dan kelas Kedokteran umum Universitas Tanjungpura Pontianak. Penelitian ini dilakukan dengan menggabungkan kuliah online dengan discord yang melibatkan dua kelas yang berbeda.

Pada penelitian ini merupakan penelitian kualitatif karena penelitian tersebut dapat menghasilkan kesimpulan secara umum dan hasil dari penelitian tersebut didapatkan dari pengujian secara empiris di lapangan[11], dan dijelaskan secara detail mengenai penerapan dan pemanfaatan aplikasi discord sebagai media pembelajaran yang baru di era digital ini. Pendekatan kualitatif secara naturalis serta digunakan sebagai metode yang dapat mendeskripsikan fakta bahwa aplikasi discord dapat dimanfaatkan sebagai media pembelajaran.

\section{HASIL DAN PEMBAHASAN}

Media pembelajaran yang berbasis teknologi dan informasi banyak membantu para pendidik di lingkungan sekolah mendapatkan informasi serta kemudahan dalam belajar diluar kelas [12]. Bagi seorang pendidik, adalah sebuah kewajiban dan tuntutan zaman modern untuk bisa menggunakan serta memanfaatkan kemajuan teknologi informasi dan komunikasi. Oleh sebab itu, perlunya para pendidik yang lahir sebelum era digital harus mempunyai kompetensi yang sesuai standar perkembangan zaman. Salah satu bentuk perwujudan pemanfaatan teknologi informasi dalam pembelajaran adalah dengan membuat media pembelajaran yang berbasis teknologi informasi yang relevan dengan keadaan sekarang, sebab Perkembangan teknologi informasi yang semakin hari semakin cepat berdampak pada pada pola pikir, karakter hingga tingkah laku manusia. Pendidikan juga tidak luput dari dampak perkembangan zaman yang semakin terus berubah. Bahkah dinamisasi proses belajar mengajar di kelas tidak hanya dilakukan di dalam ruangan kelas tetapi bisa dilakukan di rumah dan dimana saja.

Perkembangan teknologi era digital menuntut seorang pendidik untuk dapat berinovasi dan beradaptasi dalam memanfaatkan teknologi sebagai media dalam proses pembelajaran[13]. Ini berdampak pada peralihan dari gaya mengajar konvensional menjadi pembelajaran hybrid learning dan blended learning [14], contoh dari media pembelajaran berbasis elektronik seperti televisi, radio, google book, koran online, majalah online, dan sebagainya bisa pendidik gunakan sebagai alat dalam proses pembelajaran. 
Dengan adanya perkembangan teknologi informasi dan komunikasi hasilnya adalah para pendidik dapat memanfaatkannya sebagai media pembelajaran. Oleh karena itu tuntutan akan munculnya ide serta kreatifitas seorang pendidik kepada peserta didik baik dalam bentuk penyampaian materi maupun presentasi harus di ubah supaya menjadi lebih menarik, contoh dengan menggunakan aplikasi discord yang dapat membuat interaksi sosial dalam pembelajaran menjadi lebih hidup, dan interaktif sehingga mempunyai daya tarik tersendiri bagi peserta didik [15].

Aplikasi discord bahkan dapat menggabungkan beberapa item seperti mengupload presentasi semisal file PPT, Doc, Gambar, Video dan PDF seperti yang terlihat pada Gambar 1. Aplikasi discord juga dapat dipakai sebagai media dan sarana dosen dan mahasiswa bertukar pikiran antar kelas maupun antar universitas. Ini sudah dilakukan oleh penulis, bagaimana penulis menggabungkan dua kelas yang berbeda yaitu kelas Pendidikan Kewarganegaraan dengan Kelas Kedokteran Umum dalam satu mata kuliah yang sama yaitu kuliah Pancasila. Metode dalam pembelajaran yang digunakan adalah ceramah, presentasi dan debat antar kelompok kelas yang berbeda. Bahkan tidak hanya itu, saat perkuliahan berlangsung juga dilibatkan dosen dari luar universitas lain untuk memberikan masukan dan sharing kuliah bersama menggunakan aplikasi discord.

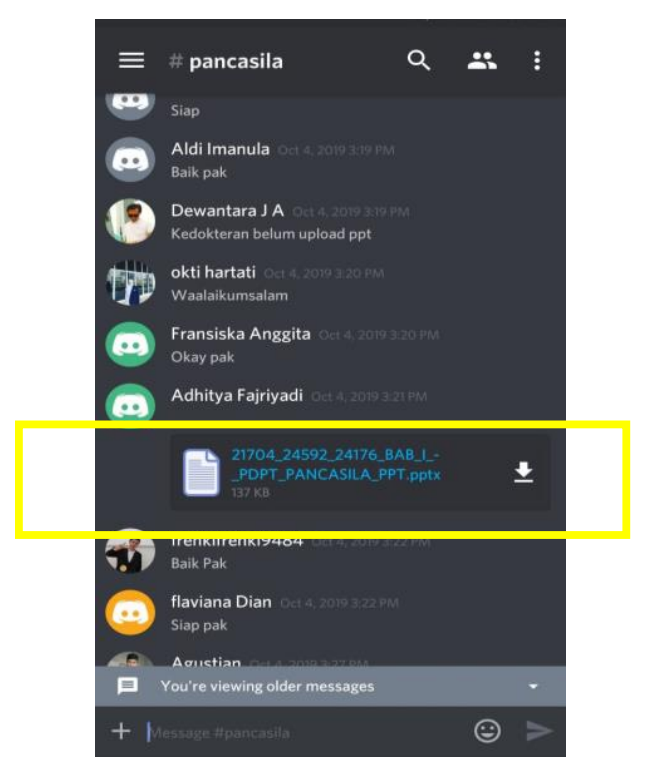

Gambar 1. File ppt. yang diupload melalui aplikasi discord

Awal aplikasi Discord muncul dimulai dari sebuah perkumpulan gamer yang pada dasarnya untuk sarana mereka dalam melakukan komunikasi[16].

Pola interaksi dan komunikasi yang peneliti lakukan saat mengunakan aplikasi discord adalah ikut berpatisipasi dan mengamati di dalam group discord tersebut, dalam observasi tersebut peneliti mengamati setiap keadaan yang terjadi didalamnya dan ikut dalam aturan yang sudah peneliti rancang dan dibuat untuk berkomunikasi di dalam group discord tersebut. Diskusi di dalam group discord dilakukan dengan peraturan, yang pertama adalah ketika ada salah seorang yang berbicara atau melakukan presentasi wajib para anggota untuk men-silent semua aktifitas yang berkaitan dengan voice, ini adalah sebuah etika dalam berkomukasi dalam group discord. Komunikasi merupakan sebuah interaksi sosial antara seorang komunikator dalam menyampaikan sebuah argumentasi kepada komunikan, dalam konteks ini juga melibatkan peran media tertentu sehingga menghasilkan sebuah umpan balik serta respon [17]. Sesuai dengan pola komunikasi dan interaksi yang terjadi pada mata kuliah Pancasila yang juga menggunakan sebuah media yaitu aplikasi discord, aplikasi tersebut sangat berguna sebagai media menyampaikan pendapat dan argumentasi para member bahkan menjadi ajang debat antara kelas kedokteran dan Pendidikan kewarganegaraan.

Peraturan kedua dalam grup discord adalah mahasiswa mengupload materi kuliahnya yang berbentuk makalah serta PPT untuk dipresentasikan online pada saat kuliah. Presentasi dilakukan bergantikan setiap kelompoknya dan hanya satu orang saja yang boleh menyampaikan presentasi secara bergantian. Hal tersebut bertujuan agar terjadinya ajang saling tukar pendapat dan informasi karena diperlukan pandangan yang berbeda dari setiap kelompok dalam menyikapi masalah yang dibahas dalam perkuliahan.

Aplikasi discord juga digunakan sebagai perantara mahasiswa dan dosen untuk berkomunikasi apabila dosen tidak dapat hadir di kelas dan juga aplikasi discord juga mempunyai manfaat lain yaitu sebagai sarana mempererat komunikasi lintas universitas maupun negara. Sementara untuk mahasiswa yang telah bergabung dalam server mata kuliah Pancasila, dapat memanfaatkan group aplikasi discord sebagai sarana dalam berkomunikasi serta mencari dan menambah rekan dalam lintas keilmuan yang sama maupun berbeda. Para anggota setelah selesai perkulihan juga dapat melakukan interaksi di luar kuliah, pertukaran tersebut meliputi pesan, informasi, dan percakapan lainnya. Tidak hanya itu ketika para anggota yang telah bergabung dalam sebuah group discord lain juga dapat memasuki channel yang sudah tersedia dan dapat berkomunikasi dengan anggota group didalamnya. Komunikasi juga bisa dilakukan dengan tiga cara, yaitu komunikasi chat text yang disampaikan melalui lobby chat dengan 
cara mengetikan pesan di aplikasi discord tersebut. Cara yang kedua adalah dengan cara voice chat, dan cara yang terakhir adalah dengan cara menggabungkan voice chat dan chat text, sebagai misal ada anggota yang ingin menyampaikan pendapat atau membantah pendapat anggota lain harus izin masuk melalui chat text. Oleh karena itu pola interaksi di dalam pembelajaran online tidak hanya melibatkan satu aspek aplikasi saja tetapi bisa mengkobinasikan dengan aplikasi lain untuk mempermudah komunikasi antar anggota discord [18].

Dari hasil wawancara yang diperoleh bahwa aplikasi Ini dapat menjadi sebuah motivasi dan juga sebuah alternatif lain kepada para pendidik ketika akan menggunakan aplikasi Discord sebagai media dalam kuliah online. Dari hasil observasi dan penjelaskan di atas, bahwa aplikasi Discord memiliki dua metode atau media yang dapat dgunakan oleh pendidik, yaitu Text Channel dan Voice Channel. Text Channel dapat digunakan untuk melakukan aktivitas chatting seperti mengetik dan menulis layaknya aplikasi LMS Moodle dan Whatsapp, serta Google Class Room [19]. Aplikasi discord juga mempunyai kelebihan lain, yakni dalam satu Text Channel pemilik server dapat membagi-bagi berdasarkan tema dan topik kuliah yang ingin dibahas. Seperti server pada Kuliah Umum Pancasila yang di dalam text channel-nya terbagi menjadi 4 spot channel, yakni: 1) Chat-umum, 2) Pancasila, 3) absen-ppknpancasila, dan 4) absen-kedokteran-pancasila. Seperti Gambar 2 berikut:

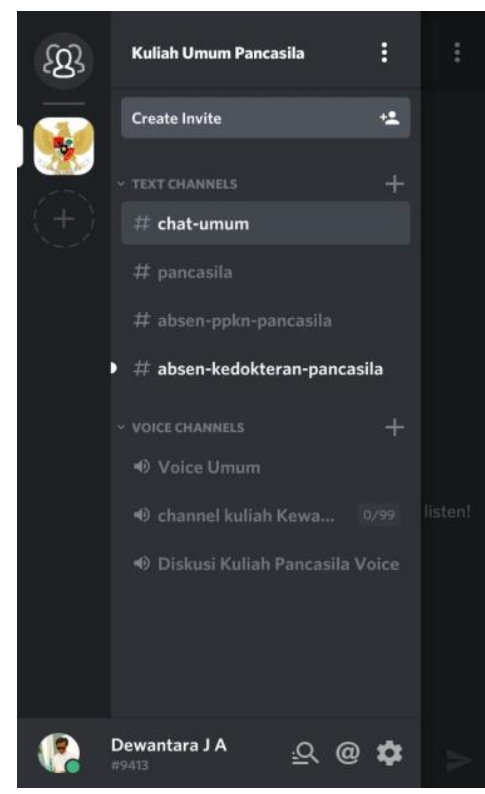

Gambar 2. Text channel dan voice channel discord

Ini dikhususkan dan diatur agar semua anggota group lebih mudah dalam melakukan aktivitas diskusi online karena sudah ditentukan tema dan tujuan setiap Text Channel. Beralih ke mode Voice Channel, di dalam mode ini para anggota group dapat berdiskusi mengunakan Voice note atau berbicara langsung.

Pada mode ini suara yang dihasilkan di Voice channel sangat jernih tetapi tidak menutup kemungkinan bergantung juga pada sinyal dan wifi serta jaringan yang kita gunakan. Tidak jauh berbeda dalam Text channel juga terbagi menjadi 3 mode yaitu \#Voice-umum, \#kuliah-kewarganegaraan dan \#diskusi-kuliah-pancasila.

Masing-masing mode punya fungsi dan tujuan sendiri-sendiri. Untuk dapat bergabung di dalam obrolan voice channel maupun text channel, untuk melakukan hal tersebut maka terlebih dahulu harus menekan tombol yang bertuliskan connect to voice pada channel yang dipilih sebelumnya. Jika berhasil masuk dan terhubung, maka secara otomatis profil akan muncul di channel tersebut. Hal tersebut juga diungkapkan oleh salah seorang informan yang juga dapat menggunakan speaker ponsel atau headset dalam menjalin komunikasi di Aplikasi discord, jika hanya ingin menjadi pendengar tanpa harus berbicara, maka dapat mengunakan tombol off pada mikrofon yang terdapat di voice channel tersebut, tetapi jika ingin memulai pembicaraan dapat mengaktifkanya kembali.

\section{KESIMPULAN}

Kemajuan teknologi dan informasi sangat mendukung dunia pendidikan. Pemanfaatan teknologi sebagai media dan informasi pembelajaran, dapat dengan mudah digunakan oleh para pendidik dan juga oleh peserta didik. Artikel ini telah memperkaya media pembelajaran melalui pemanfaatan aplikasi discord sebagai media pembelajaran online (daring).

Discord menyediakan kemudahan dalam pembelajaran, diantaranya: (1) pembelajaran tidak terikat oleh ruang kelas, (2) dapat digunakan untuk mata kuliah/ mata pelajaran yang sama untuk 2 atau lebih kelas yang berbeda, (3) menyediakan fitur-fitur yang mendorong terjadinya interaksi dan komunikasi di antara para peserta (members) (4) memungkinkan pembelajaran memiliki lebih dari 2 dosen atau ahli, (5) interaksi dapat dilakukan dengan Text chanel dan voice chanel.

\section{SARAN}

Bedasarkan hasil penelitian ini, terdapat beberapa hal yang menjadi saran yaitu sebagai berikut:

1. Perlu dilakukan pengkajian tentang tingkat kepuasan peserta didik dalam menggunakan Aplikasi Discord. 
2. Dalam menggunakan aplikasi discord, sebaiknya menggunakan kombinasi LMS MoodleI dan aplikasi lainya yang mampu menambah efektivitas penggunakan kuliah daring.

3. Penggunaan aplikasi discord, sebaiknya memakai headset atau melakukan sosialisasi terlebih dahulu kepada peserta didik.

\section{DAFTAR PUSTAKA}

[1] I. Ahmad, "Digital learning process in the age of the industrial revolution 4.0 era technology disruptions," Minist. Res. Technol. High. Educ, pp. 1-13, 2018.

[2] A. D. Samala, B. R. Fajri, and F. Ranuharja, "DESAIN DAN IMPLEMENTASI MEDIA PEMBELAJARAN BERBASIS MOBILE LEARNING MENGGUNAKAN MOODLE MOBILE APP," J. Teknol. Inf. dan Pendidik., vol. 12, no. 2, pp. 13-19, Dec. 2019.

[2] A. Margaryan, S. Researcher, B. Collis, and A. Cooke, "Activity-based blended learning," Hum. Resour. Dev. Int., no. December 2014, pp. $37-41,2014$.

[3] L. De George-walker and M. Keeffe, "Selfdetermined blended learning : a case study of blended learning," High. Educ. Res. Dev., vol. 29, no. 1, pp. 1-13, 2010.

[5] M. L. Hidayat, W. H. Prasetiyo, and J. Wantoro, "Pre-Service Student Teachers ' Perception of Using Google Classroom in a Blended Course," Humanit. Soc. Sci. Rev., vol. 7, no. 2, pp. 363368, 2019.

[6] J. P. Raihan and Y. R. Putri, "Pola Komunikasi Group Discord PUBG.INDO.FUN Melalui Aplikasi Discord," e-Proceeding Manag., vol. 5, no. 3, pp. 4161-4169, 2018.

[7] M. Kearney, S. Schuck, K. Burden, and P. Aubusson, "Viewing mobile learning from a pedagogical perspective," J. Res. Learn. Technol., vol. 20, no. 1, pp. 1-18, 2012.

[8] J. W. Creswell, Research Design: Qualitative, Quantitative, and Mixed Methods Approaches, Third Edit. London: SAGE Publications, Inc, 2009.

[9] J. A. Dewantara and D. Budimasyah, "Mutual Cooperation Based Go Green: New Concept of Defense Country," Educ. Humanit. Res., vol. 251, no. Acec 2018, pp. 38-45, 2018.

[10] M. Miles and M. Huberman, Qualitative data analysis : an expanded sourcebook / Matthew B. Miles, A. Michael Huberman., Second Edi.
London: Sage Publications, Inc., 1994.

[11] W. H. Prasetiyo, K. R. Kamarudin, and J. A. Dewantara, "Surabaya green and clean: Protecting urban environment through civic engagement community," J. Hum. Behav. Soc. Environ., vol. 29, no. 8, pp. 997-1014, 2019.

[12] J. A. Dewantara, Efriani, Sulistyarini, and W. H. Prasetiyo, "Optimization of Character Education Through Community Participation Around The School Environment ( Case Study in Lab School Junior High School Bandung )," J. Etika Demokr., vol. 5, no. 1, pp. 53-66, 2020.

[13] R. Yudhi and S. Priana, "Pemanfaatan Vlog Sebagai Media Pembelajaran," in Seminar Nasional Pendidikan FKIP UNTIRTA, 2017, pp. 313-316.

[14] A. Hwang, "Online and Hybrid Learning," J. Manag. educition, no. 2000, pp. 1-7, 2018.

[15] M. Amiryousefi, "The incorporation of flipped learning into conventional classes to enhance EFL learners ' L2 speaking, L2 listening , and engagement," Innov. Lang. Learn. Teach., vol. 0, no. 0, pp. 1-15, 2017.

[16] A. N. Wulanjani, "Discord Application:Turning a Voice Chat Application for Gamers into a Virtual Listening Class," in 2nd English Language and Literature International Conference, 2018, vol. 2, pp. 115-119.

[17] J. B. Houston and P. M. Buzzanell, "Communication and resilience: introduction to the Journal of Applied Communication Research special issue," vol. 9882, 2020.

[18] O. Casquero, J. Portillo, R. Ovelar, and J. Romo, "iPLE Network: an integrated eLearning 2.0 architecture from a university ' $\mathrm{s}$ perspective," Interact. Learn. Environ., no. January 2015, pp. 37-41, 2015.

[19] K. Laeeq, Z. A. Memon, and K. Laeeq, "Scavenge : an intelligent multi-agent based voice- enabled virtual assistant for LMS Scavenge: an intelligent multi-agent based voice-enabled virtual," Interact. Learn. Environ., vol. 0, no. 0, pp. 1-19, 2019. 